\title{
PERBANDINGAN KUAT GESER TANAH PASIR MENGGUNAKAN GEOTEXTILE WOVEN DAN NON WOVEN BERDASARKAN UJI DIRECT SHEAR
}

\author{
Drebya Septanie Rishavilenda ${ }^{1}$, Asriwiyanti Desiani ${ }^{2}$ \\ ${ }^{1}$ Mahasiswa Program Studi S1 Teknik Sipil, Universitas Kristen Maranatha \\ Jl. Prof. drg. Soeria Sumantri, MPH., No. 65, Bandung, 40164 \\ Email:drebyas@gmail.com \\ ${ }^{2}$ Dosen Program Studi S1 Teknik Sipil, Universitas Kristen Maranatha \\ Jl. Prof. drg. Soeria Sumantri, MPH., No. 65, Bandung, 40164 \\ Email: asriwiyanti@gmail.com
}

\begin{abstract}
ABSTRAK
Pada tanah yang memiliki daya dukung rendah, perlu dilakukan perbaikan. Salah satu inovasi untuk perbaikan tanah yaitu melakukan perkuatan dengan menggunakan geotextile. Dalam perencanaan daya dukung tanah dibutuhkan parameter kuat geser tanah yaitu c dan $\phi$. Direct shear merupakan salah satu alat yang sering digunakan untuk mendapatkan parameter kuat geser tanah. Oleh karena itu akan dianalisis perbandingan kuat geser tanah pasir dengan menggunakan perkuatan geotextile woven, non woven dan tanpa geotextile. Kecepatan geser yang digunakan adalah kecepatan A. Beban yang digunakan untuk uji coba yaitu: 961,3gr; 1922,7gr; dan 3845,1 gr. Klasifikasi tanah yang dilakukan pada pengujian ini adalah well graded sand with gravel. Nilai angka pori pada pengujian ini ditetapkan untuk menghitung berat sampel yang masuk kedalam uji direct shear.

Hasil penelitian ini menunjukkan bahwa nilai sudut geser dalam $(\phi)$ SU1 sebesar $31,75^{\circ}$ dengan kohesi (c) sebesar $13,265 \mathrm{kPa}$. Nilai sudut geser dalam $(\phi)$ untuk SU2 dan SU3 berturut-turut adalah $41,25^{\circ}$ dan $34,67^{\circ}$. Nilai kohesi (c) untuk SU2 dan SU3 berturut-turut adalah $14,646 \mathrm{kPa}$ dan $13,592 \mathrm{kPa}$. Untuk perbandingan parameter kuat geser tanah terhadap sampel uji yang menggunakan geotextile nilai sudut geser dalam $(\phi)$ dan nilai kohesi (c) lebih besar daripada sampel uji tanpa menggunakan geotextile.
\end{abstract}

Kata Kunci: direct shear, geotextile, sudut geser dalam $(\phi)$, kohesi (c), angka pori

\section{ABSTRACT}

On land that has a low bearing capacity, repairs is required to be done. One innovation for soil improvement is by reinforcement using a geotextile. In planning the bearing capacity of the soil, soil shear strength parameters are needed, namely $c$ and $\phi$. Direct shear is one of the tools that is often used to obtain the parameters of shear strength.

Therefore, it will be analyzed the ratio of sand shear strength using geotextile woven, non-woven and without geotextile reinforcement. The shear speed used is speed $A$. The load used for the trial is: 961,3gr; 1922,7gr; and 3845,1gr. The soil classification carried out in this test is well graded sand with gravel. The pore number value in this test is determined to calculate the weight of the sample entered into the direct shear test.

The results of this study indicate that the value of the shear angle in ( $\phi$ ) SU1 is $31.75^{\circ}$ with cohesion (c) of $13.265 \mathrm{kPa}$. The values of shear angles in ( $\phi)$ for SU2 and SU3 are $41.25^{\circ}$ and $34.67^{\circ}$ respectively. The cohesion values (c) for SU2 and SU3 are $14,646 \mathrm{kPa}$ and $13,592 \mathrm{kPa}$, respectively. For comparison of soil shear strength parameters against test samples using geotextile values of inner shear angle $(\phi)$ and cohesion value (c) greater than the test sample without using geotextile.

Keywords: direct shear, geotextile, angle of internal friction $(\phi)$, cohesion (c), pore number 


\section{PENDAHULUAN}

\subsection{Latar Belakang}

Membangun suatu konstruksi tidaklah mudah, sebab tanah memiliki jenis yang berbeda-beda. Ada beberapa jenis tanah, di antaranya: kerikil (gravel), pasir (sand), lanau (silt), dan lempung (clay). Jenis tanah ditentukan oleh ukuran partikel yang paling dominan pada tanah tersebut. Daya dukung tanah pun berbeda-beda, untuk pasir pada umumnya baik, tetapi bila sedang berada di kondisi jenuh, maka kuat gesernya akan berkurang (Muntohar, 2011).

Menurut Mohr (1910), keruntuhan terjadi akibat adanya kombinasi keadaan kritis dari tegangan normal dan tegangan geser. $\mathrm{C}$ dan $\phi$ adalah nilai kuat geser tanah. Makin tinggi nilai $\mathrm{c}$ dan $\phi$, maka makin tinggi kuat geser tanah tersebut. Apabila tanah pasir memiliki daya dukung tanah yang rendah, maka perlu dilakukan perkuatan tanah. Kuat geser yang rendah akan mengakibatkan terbatasnya beban yang dapat bekerja pada tanah sehingga akan menimbulkan penurunan pada bangunan.

Dalam ilmu Teknik Sipil, banyak bermunculan inovasi untuk perkuatan tanah, salah satunya dengan geosintetik. Geosintetik adalah produk buatan pabrik dari bahan polymer. Salah satu bahan geosintetik yang banyak digunakan adalah geotekstil. Geotekstil memiliki 2 jenis yang berbeda, yaitu: woven dan non woven. Geotekstil woven terbuat dari silt film tape polypropylene yang penggunaannya kini beredar luas di Indonesia, sedangkan geotekstil non woven adalah salah satu jenis berbentuk lembaran tak beranyam yang dibuat dari serat polymer berbahan dasar polypropylene/polyester. Manfaat dari penggunaan geotekstil antara lain: untuk separasi, stabilisasi, perkuatan, filtrasi, lapis kedap, drainase, proteksi, pembungkus, dan penahan erosi.

Tujuan penelitian ini untuk menguji kuat geser tanah pasir dengan menggunakan perkuatan geotekstil dan tanpa geotekstil. Percobaan untuk menguji kuat geser tanah pasir ini menggunakan direct shear. Parameter yang ingin ditemukan adalah $\mathrm{c}$ dan $\phi$.

\subsection{Tujuan dan Ruang Lingkup Penelitian}

Tujuan penelitian Penelitian ini adalah menganalisis perbandingan kuat geser $(c$ dan $\phi$ ) tanah pasir menggunakan perkuatan geotekstil woven, non woven dan tanpa geotekstil.

Ruang lingkup penelitian adalah:

1.Bahan uji yang digunakan adalah tanah pasir dari proyek jalan tol Cisumdawu, Cimalaka, Sumedang;

2.Menggunakan perkuatan geotekstil woven tipe silt film dan non woven tipe melt bonded; 
3. Alat percobaan yang akan digunakan yaitu alat direct shear (ASTM D3080);

4. Geotekstil diletakkan 1/3h dari bawah sampel uji;

5.Kecepatan geser yang digunakan adalah $0,553 \mathrm{~mm} / \mathrm{menit}$;

6. Beban kerja yang digunakan untuk uji coba 961,3 gr;

7.Percobaan dilakukan di Laboratorium Mekanika Tanah, Program Studi S-1 Teknik Sipil Universitas Kristen Maranatha.

\section{Gambar 1. Dukuh Atas, tempat bertemunya 5 moda transportasi Jakarta}

\section{TINJAUAN PUSTAKA}

\subsection{Parameter Indeks Properti Tanah}

Sifat-sifat indeks properti menunjukkan sifat-sifat tanah yang mengindikasi jenis dan kondisi tanah, serta memberikan hubungan terhadap sifatsifat mekanis (engineering properties) seperti kekuatan dan pemampatan atau kecenderungan untuk mengembang dan permeabilitas (Muntohar, 2005). Indeks properti tanah yang umum diteliti adalah berat isi tanah, berat jenis, kadar air, angka pori, porositas, dan derajat kejenuhan.

Berat isi tanah asli adalah berat tanah utuh (undisturbed) dibagi dengan volume tanah (Agus et al. 2006). Berat isi tanah asli biasanya pada rentang 17$22 \mathrm{kN} / \mathrm{m}^{3}$. Sama hal nya dengan berat isi tanah kering yaitu berat tanah kering dibagi dengan volume tanah dengan rentang $14-18 \mathrm{kN} / \mathrm{m}^{3}$. Untuk nilai berat isi tanah kering maksimum (keadaan pasir paling padat) dan minimum (keadaan pasir paling lepas) biasanya memiliki rentang nilai $15-19 \mathrm{kN} / \mathrm{m}^{3}$ dan $13-17 \mathrm{kN} / \mathrm{m}^{3}$. Berat isi tanah jenuh $\left(\gamma_{\mathrm{s}}\right)$ adalah berat isi tanah di mana tanah tersebut berada dalam kondisi jenuh, sedangkan berat isi tanah basah adalah keadaan di mana tanah tersebut berada dalam kondisi tanah basah. Bila tanah terendam air, dinyatakan sebagai berat isi efektif $\left(\gamma_{e f f}\right)$.

Berat spesifik atau berat jenis (specific gravity) tanah (Gs) adalah perbandingan antara berat volume butiran padat $\left(\gamma_{\mathrm{s}}\right)$, dengan berat volume air $\left(\gamma_{\mathrm{w}}\right)$ pada temperatur ruangan (Hardiyatmo, 2002). Untuk pasir biasanya memiliki rentang 2,6-2,7.

Kadar air (water content) adalah perbandingan antara berat air $\left(\mathrm{W}_{\mathrm{w}}\right)$ dengan berat butiran padat $\left(\mathrm{W}_{\mathrm{s}}\right)$ dalam tanah tersebut (Hardiyatmo, 2002). 
Biasanya kadar air memiliki rentang tipikal $10 \%-40 \%$, tetapi pada kenyataannya kadar air dapat memiliki rentang 0 - $\square$.

Derajat kejenuhan $(\mathrm{S})$ adalah perbandingan volume air $\left(\mathrm{V}_{\mathrm{w}}\right)$ dengan volume total rongga pori tanah $\left(\mathrm{V}_{\mathrm{v}}\right)$. biasanya dinyatakan dalam persen. Bila tanah dalam keadaan jenuh air, maka $\mathrm{S}=1$.

Porositas $(n)$ adlah perbandingan antara volume rongga $\left(\mathrm{V}_{\mathrm{v}}\right)$ dengan volume total (V). Nilai $n$ dapat dinyatakan dalam persen atau desimal. Biasanya memiliki rentang tipikal 25-50\%.

Angka pori (e) didefinisikan sebagai perbandingan antara volume rongga $\left(\mathrm{V}_{\mathrm{v}}\right)$ dengan volume butiran $\left(\mathrm{V}_{\mathrm{s}}\right)$, biasanya dinyatakan dalam desimal. Biasanya memiliki rentang tipikal 0,4-1. Untuk angka pori maksimum (pasir dalam keadaan paling lepas) biasanya memiliki rentang tipikal sebesar 0,6-1,2. Sedangkan angka pori minimum (pasir dalam keadaan paling padat) biasanya memiliki rentang tipikal sebesar 0,3-0,9.

Untuk rentang tipikal tanah pada umumnya dapat dilihat pada Gambar 1.

\begin{tabular}{|c|c|c|c|c|}
\hline Parameter & Symbol & Definition & Typical range & Observation \\
\hline Total unit weight & $\gamma_{\mathrm{t}}$ & $\mathrm{W}_{\mathrm{t}} / V_{t}$ & $17-22 \mathrm{kN} / \mathrm{m}^{3}$ & $\begin{array}{l}\text { Unit weight of soil in natural } \\
\text { state }\end{array}$ \\
\hline Dry unit weight & $\gamma_{a}$ & $\mathrm{~W}_{\mathrm{s}} / V_{t}$ & $14-18 \mathrm{kN} / \mathrm{m}^{3}$ & Unit weight of dry soil \\
\hline Maximum dry unit weight & $\gamma_{\text {amax }}$ & $\mathrm{W}_{\mathrm{smax}} / V_{t}$ & $15-19 \mathrm{kN} / \mathrm{m}^{3}$ & Densest state \\
\hline Minimum dry unit weight & $\gamma_{\mathrm{dmin}}$ & $\mathrm{W}_{\mathrm{smin}} / V_{t}$ & $13-17 \mathrm{kN} / \mathrm{m}^{3}$ & Loosest state \\
\hline Unit weight of solids & $\gamma_{\mathrm{s}}$ & $\mathbf{W}_{\mathrm{s}} / \boldsymbol{V}_{\mathrm{s}}$ & $\begin{array}{l}25.5-27 \mathrm{kN} / \mathrm{m}^{3} \text { for } \\
\text { mineral } \\
9-13 \mathrm{kN} / \mathrm{m}^{3} \text { for organic }\end{array}$ & Unit weight of particles \\
\hline Specific gravity of solids & $\mathbf{G}_{\mathrm{s}}$ & $\gamma_{\mathrm{s}} / \gamma_{\mathrm{w}}$ & $\begin{array}{l}2.6-2.7 \text { for mineral } \\
0.9-1.3 \text { for organic }\end{array}$ & Dimensionless \\
\hline Saturated unit weight & $\gamma_{\text {sat }}$ & $\left(\mathbf{W}_{\mathrm{s}}+V_{v} \gamma_{w}\right) / V_{t}$ & $18-22 \mathrm{kN} / \mathrm{m}^{3}$ & Voids are full of water \\
\hline Submerged unit weight & $\gamma_{\text {sub }}$ & $\gamma_{\mathrm{sat}}-\gamma_{\mathrm{w}}$ & $8-12 \mathrm{kN} / \mathrm{m}^{3}$ & Buoyancy force accounted for \\
\hline Effective unit weight & $\gamma_{\text {eff }}$ & $\begin{array}{l}\gamma_{\mathrm{t}} \text { if above GWL } \\
\gamma_{\mathrm{sat}}-\gamma_{w} \text { if below GWL }\end{array}$ & See $\gamma_{\mathrm{t}}$ and $\gamma_{\text {sub }}$ & \\
\hline Unit weight of water & $\gamma_{w}$ & $\mathrm{~W}_{w} / V_{w}$ & $9.81 \mathrm{kN} / \mathrm{m}^{3}$ & \\
\hline Water content (gravimetric) & $w$ & $W_{w} / W_{s}$ & $10-40 \%$ & $0-\infty$ theoretical range \\
\hline Volumetric water content & $\theta_{w}$ & $V_{w} / V_{t}$ & $5-30 \%$ & $0-1$ theoretical range \\
\hline Degree of saturation & $\mathrm{s}$ & $V_{w} / V_{v}$ & $50-100 \%$ & $0-100 \%$ theoretical range \\
\hline Porosity & $\mathbf{n}$ & $V_{v} / V_{t}$ & $25-50 \%$ & $0-100 \%$ theoretical range \\
\hline Void ratio & $e$ & $V_{v} / V_{s}$ & $0.4-1$ & $0-\infty$ theoretical range \\
\hline Maximum void ratio & $e_{\max }$ & $V_{\mathrm{vmax}} / V_{\mathrm{s}}$ & $0.6-1.2$ & Loosest state \\
\hline Minimum void ratio & $e_{\min }$ & $V_{\mathrm{vmin}} / V_{\mathrm{s}}$ & $0.3-0.9$ & Densest state \\
\hline Density Index & $I_{d}$ or $D_{r}$ & $\left(e_{\max }-e\right) /\left(e_{\max }-e_{\min }\right)$ & $20-90 \%$ & $0-100 \%$ theoretical range \\
\hline
\end{tabular}

Gambar 1. Parameter Indeks Properti dan Rentang Tipikal Sumber: Briaud, 2013

\subsection{Kuat Geser Tanah}

Parameter kuat geser tanah diperlukan untuk analisis-analisis kapasitas dukung tanah, stabilitas lereng dan gaya dorong pada dinding penahan tanah. Menurut teori Mohr (1910) kondisi keruntuhan suatu bahan terjadi oleh akibat adanya kombinasi keadaan krisis dari tegangan normal dan tegangan geser. 
Hubungan fungsi antara tegangan normal dan tegangan geser pada bidang runtuhnya, dinyatakan oleh Persamaan 1

$$
\tau=f(\sigma)
$$

dengan $\tau$ adalah tegangan geser pada saat terjadinya keruntuhan atau kegagalan (failure), dan $\sigma$ adalah tegangan normal pada saat kondisi tersebut. Garis kegagalan yang didefinisikan dalam Persamaan 1, adalah kurva yang ditunjukkan dalam Gambar 2.

Kuat geser tanah adalah gaya perlawanan yang dilakukan oleh butir-butir tanah terhadap desakan atau tarikan. Dengan dasar pengertian ini, bila tanah mengalami pembebanan akan ditahan oleh:

(1) Kohesi tanah yang bergantung pada jenis tanah dan kepadatannya, tetapi tidak bergantung dari tegangan normal yang bekerja pada bidang geser.

(2) Gesekan antara butir-butir tanah yang besarnya berbanding lurus dengan tegangan normal pada bidang gesernya.

Coulomb (1776) mendefinisikan $f(\sigma)$ seperti pada Persamaan 2

$$
\tau=c+\sigma \tan \phi
$$

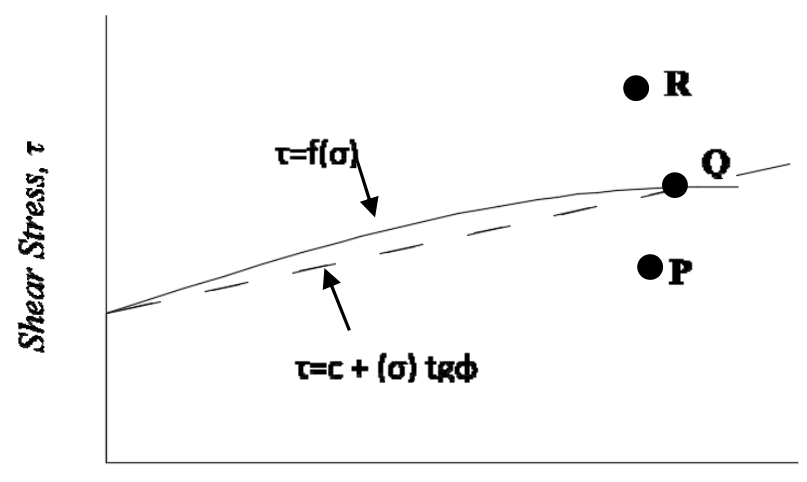

Normal Stress, $\sigma$

Gambar 2. Kriteria Kegagalan Mohr-Coulomb

Sumber: Hardiyatmo, 2002

dengan:

$\tau=$ kuat geser tanah $\left(\mathrm{kN} / \mathrm{m}^{2}\right)$

$c=$ kohesi tanah $\left(\mathrm{kN} / \mathrm{m}^{2}\right)$

$\phi=$ sudut geser dalam tanah atau sudut geser intern (derajat)

$\sigma=$ tegangan normal pada bidang runtuh $\left(\mathrm{kN} / \mathrm{m}^{2}\right)$

Perbandingan Kuat Geser Tanah Pasir Menggunakan Geotextile Woven Dan Non Woven 
Persamaan 2 ini disebut kriteria keruntuhan atau kegagalan MohrCoulomb, di mana garis selubung kegagalan dari persamaan tersebut dilukiskan dalam Gambar 2. Pengertian mengenai keruntuhan suatu bahan dapat diterangkan sebagai berikut, jika tegangan-tegangan baru mencapai titik $\mathrm{P}$, keruntuhan tanah akibat geser tidak akan terjadi. Keruntuhan geser akan terjadi jika tegangan mencapai titik Q yang terletak pada garis selubung kegagalan (failure envelope). Kedudukan tegangan yang ditunjukkan oleh titik $\mathrm{R}$ tidak akan pernah terjadi, karena sebelum tegangan yang terjadi mencapai titik $R$, bahan sudah mengalami keruntuhan (Hardiyatmo, 2002).

\subsection{Uji Geser Langsung (Direct Shear)}

Perlu diperhatikan bahwa tahanan geser puncak pada uji tegangan-terkendali besamya hanya dapat diperkirakan saja. Ini disebabkan keruntuhan terjadi hanya pada tingkat tegangan geser sekitar puncak antara penambahan beban sebelum runtuh sampai sesudah runtuh. Meskipun demikian, uji tegangan-terkendali lebih menyerupai keadaan sesungguhnya keruntuhan di lapangan dari pada uji regangan-terkendali.

Pada pengujian tertentu, tegangan normal dihitung menggunakan Persamaan 3.

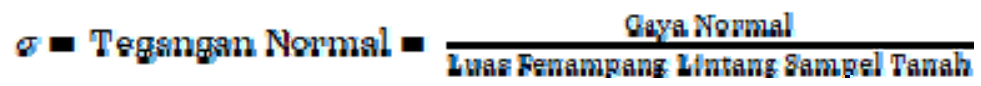

Tegangan geser yang melawan pergerakan geser dihitung menggunakan Persamaan 4.

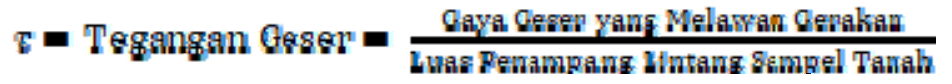

Dalam Gambar 3 terlihat potongan grafik yang umum tentang hubungan antara tegangan geser dan perubahan ketinggian (tebal) dari sampel tanah akibat perpindahan geser tanah pasir lepas dan pasir padat. Pengamatan ini dihasilkan oleh uji reganganterkendali. Hal-hal umum yang dapat ditarik dari Gambar 3 berkaitan dengan variasi tegangan geser penghambat dan perpindahan geser, yaitu:

1. Pada pasir lepas (renggang), tegangan geser penahan akan membesar sesuai dengan membesarnya perpindahan geser sampai tegangan tadi mencapai tegangan geser runtuh $\tau_{f}$ Setelah itu, besar tegangan geser akan kira-kira konstan sejalan dengan bertambahnya perpindahan geser.

2. Pada pasir padat, tegangan geser penghambat akan naik sejalan dengan membesamya perpindahan geser hingga tegangan geser runtuh (maksimum) $\tau_{f}$ tercapai. Harga $\tau_{f}$ ini disebut sebagai kekuatan geser puncak (peak shear strength). Bila tegangan runtuh 
telah dicapai, maka tegangan geser penghambat yang ada akan berkurang secara lambat laun dengan bertambahnya perpindahan geser sampai pada suatu saat mencapai harga konstan yang disebut kekuatan geser akhir maksimum (ultimate shear strength).
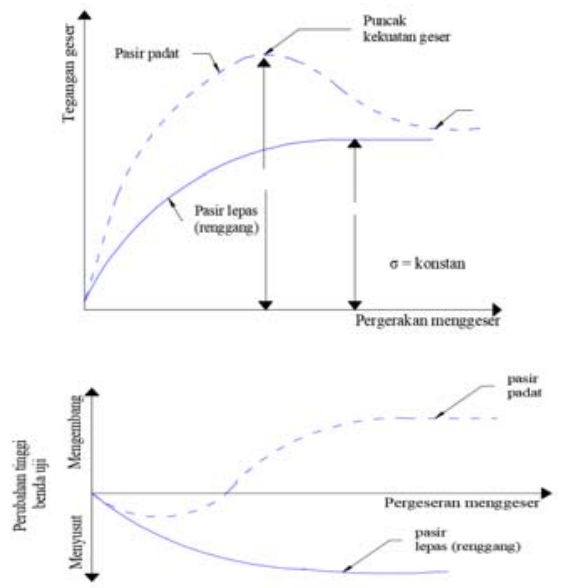

\section{Gambar 3. Diagram Tegangan Geser versus Perubahan Tinggi Benda Uji karena Pergerakan Geser untuk Tanah Pasir (Uji Direct Shear) Sumber: Das, 1994}

Uji geser langsung biasanya dilakukan beberapa kali pada sebuah sampel tanah dengan bermacam-macam tegangan normal. Harga tegangan-tegangan normal dan harga $\tau_{f}$ yang didapat dengan melakukan beberapa kali pengujian dapat digambarkan pada sebuah grafik dan selanjutnya dapat ditentukan harga-harga parameter kekuatan geser.

Pada Gambar 4 dapat dilihat grafik dari sebuah uji pada tanah pasir kering. Harga rata-rata garis yang menghubungkan titik-titik dalam eksperimen dihitung menggunakan Persamaan 5.

$$
\tau_{f}=\sigma \tan \phi
$$

(Catatan: $c=0$ untuk pasir dan $\sigma=\sigma^{\prime}$ )

Jadi, besar sudut geser dihitung menggunakan Persamaan 6.

$$
\phi-\tan ^{-1}\left(\frac{w}{\sigma}\right)
$$




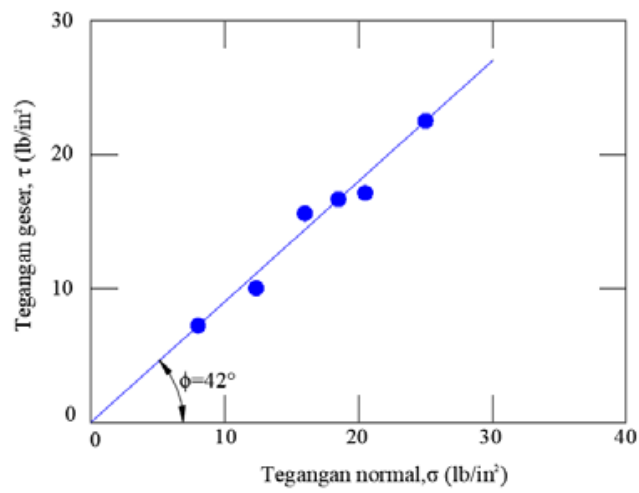

Gambar 4. Penentuan Parameter Kekuatan Geser untuk Tanah Pasir Sebagai Hasil Uji Direct Shear

Sumber: Das, 1994

Nilai kuat geser $\phi^{\prime}\left(c^{\prime}=0\right)$ pada masing-masing kondisi pasir diperlihatkan pada Tabel 1.

Tabel 1. Sudut Geser Dalam $(\phi)$ Tanah Pasir

\begin{tabular}{cccccc}
\hline Compactness & Very Loose & Loose & Medium & Dense & Very Dense \\
\hline $\begin{array}{c}\text { Friction } \\
\phi\left({ }^{\circ}\right)\end{array}$ & $0-28$ & $28-30$ & $30-36$ & $36-41$ & $>42$ \\
\hline
\end{tabular}

Sumber: Allpile User's Manual, 2014

\subsection{Geotekstil}

Menurut buku Geosintetik untuk Rekayasa Jalan, salah satu bahan geosintetik yang banyak digunakan adalah geotekstil. Geotekstil merupakan material lolos air atau material tekstil bikinan pabrik yang dibuat dari bahan-bahan sintetis, seperti: polypropylene, polyester, polyethylene, nylon, polyvinyl chloride, dan campuran dari bahan-bahan tersebut. Seluruh material ini adalah thermoplastic.

Polymer yang digunakan di pabrik geotekstil, umumnya fiber-fiber geotekstil yang dibuat dari material polymeric sebagai berikut (Koerner, 2005):

1. Polypropylene (PP) ( $\pm 92 \%)$;

2. Polyester $(\mathrm{PET})( \pm 5 \%)$;

3. Polyamide (PA) (nylon) $( \pm 2 \%)$;

4. Polyethylene $(\mathrm{PE})( \pm 1 \%)$.

Polyethylene dan poplypropylene adalah polyolefins yang di antaranya mempunyai kerapatan kurang dari $1000 \mathrm{~kg} / \mathrm{m}^{3}$.

Berbagai macam bentuk geotekstil ditunjukkan dalam Gambar 5. 
(1) Geoteksil anyam (woven), yang dibuat dari serat-serat (fibers) seperti kawat memanjang tunggal (Gambar 5 a).

(2) Geotekstil anyam (woven), yang dibuat dari serat-serat pipih yang tipis memanjang (Gambar 5b).

(3) Geotekstil nir-anyam (non woven), yang terbuat dari serat-serat serabut memanjang tersusun dengan pola tidak teratur, dan kemudian secara mekanis tersusun seperti benang kusut (seperti bakmi), sehingga terbentuk material berbulu yang relatif tebal (Gambar 5c).

(4) Geotekstil nir-anyam (non woven), yang terbuat dari serat-serat yang dibuat dengan pola acak dan kemudian digabung-gabungkan pada titik sebrangnya melalui proses pemanasan atau ikatan kimia dan ditekan dengan penggilas sampai tebalnya relatif tipis (Gambar 5d.).

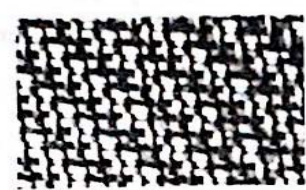

a) Anyam

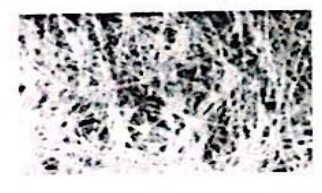

c) Nir-anyam

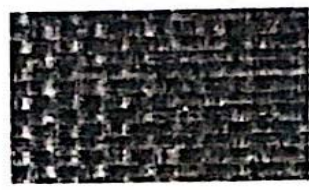

b) Anyam

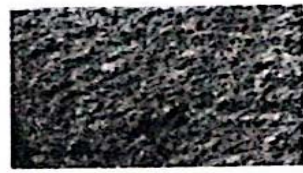

d) Nir-anyam

\section{Gambar 5 Macam-macam Tipe Geotekstil Sumber: Hardiyatmo, 2008}

Suatu hal yang amat penting terkait dengan geotekstil adalah kuat tariknya. Tipe geotekstil tertentu menentukan tipe penggunaan tertentu yang cocok, misalnya fungsi geotekstil untuk tulangan atau pemisah, filtrasi atau drainase.

Jika ditinjau menurut fungsinya, salah satu aplikasi geotekstil yang telah digunakan hingga saat ini adalah, perkuatan bangunan pada tanah lunak. Dalam fungsinya sebagai perkuatan, terutama perkuatan lereng timbunan terjal maupun landau, geotekstil diletakkan di bagian lereng dengan jarak tertentu sehingga lereng terjaga kestabilannya. Geotekstil yang diletakkan di dasar timbunan pada tanah lunak berfungsi sebagai perkuatan, sekaligus pemisah. Geotekstil juga dapat digunakan sebagai penutup material urugan yang jelek kualitasnya. Geotekstil yang dipasang antara tanah dasar dan lapis 
fondasi bawah, berfungsi kecuali untuk pemisah juga menaikkan kapasitas dukung tanah dasar yang dapat mengurangi tebal komponen perkerasan jalan.

\section{METODE PENELITIAN}

\subsection{Material Uji}

Material uji yang digunakan pada penelitian ini adalah pasir kerikil dan merupakan sampel terganggu. Kondisi sampel terganggu saat pengambilan dari hasil pasir galian Cisumdawu dapat dilihat pada Gambar 6. sehubungan kondisi tanah merupakan sampel terganggu maka selalu dilakukan pengujian kadar air pada saat akan dilakukan pengujian direct shear.

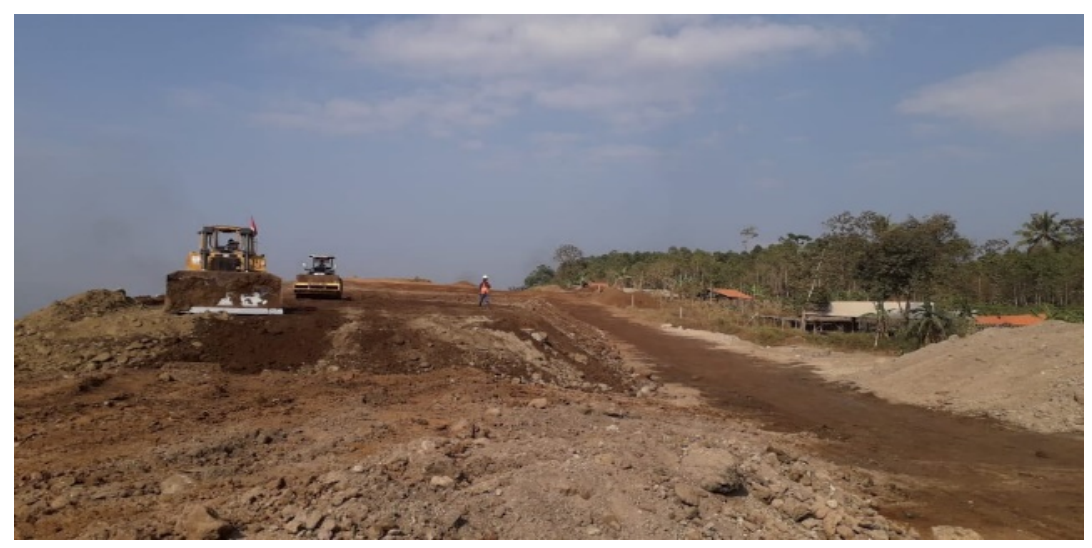

\section{Gambar 6. Pengambilan Sampel dari Proyek Tol Cisumdawu}

\subsection{Perhitungan Beban}

Berdasarkan ASTM D3080, gaya normal akan bekerja jika tuas beban diberi beban mati. Alat tersebut harus dapat menahan gaya normal sebesar $\pm 1 \%$ dari gaya yang telah ditentukan. Maka dari itu, metode untuk menentukan besarnya beban yang akan digunakan adalah:

a. Menurut Briaud (2013), pada Gambar 2 untuk $\gamma$ tanah biasanya memiliki rentang tipikal $17-22 \mathrm{kN} / \mathrm{m}^{3}$. Maka untuk perhitungan beban ini, penguji menetapkan $\gamma$ tanah pada timbunan di lapangan adalah $17 \mathrm{kN} / \mathrm{m}^{3}$.

b. Untuk tinggi timbunan tanah (h), penguji mengasumsikan nilai h. Karena pada kenyataannya, di lapangan tinggi setiap timbunan tanah berbeda-beda. Maka untuk mempermudah perhitungan, penguji menetapkan nilai $\mathrm{h}=2 \mathrm{~m}$.

c. Setelah menetapkan nilai $\gamma_{\text {timbunan }}$ dan tinggi timbunan tanah (h), maka tegangan vertikal dapat dihitung dengan menggunakan Persamaan 7. 


$$
\sigma \mathrm{v}=\text { rtmbman } \times h
$$

d. Tahap selanjutnya adalah menghitung luas dari ring direct shear yang akan dipakai saat pengujian. Menghitung luas ring direct shear dapat dihitung dengan menggunakan Persamaan 8.

$$
\mathrm{A}=\frac{1}{4} \pi d^{2}
$$

e. Setelah mendapatkan semua parameter yang dibutuhkan, maka nilai beban (P) dapat dihitung dengan menggunakan Persamaan 9.

$$
\mathrm{P}=\sigma v \times A
$$

Perhitungan manual untuk mendapatkan beban (P) dapat dilihat dibawah ini:

Diketahui:

$$
\begin{array}{ll}
\text { Berat jenis timbunan ( } \gamma \text { timbunan }) & =17 \mathrm{kN} / \mathrm{m}^{3} \\
\text { Tinggi timbunan }(\mathrm{h}) & =2 \mathrm{~m}(\text { asumsi) } \\
\text { Diameter sampel }(\mathrm{d}) & =6 \mathrm{~cm}
\end{array}
$$

Cara pengerjaan:

1. Menghitung tegangan vertikal ( $\sigma v)$ menggunakan Persamaan 7.

$$
\begin{aligned}
\sigma v & =\text { ytmbunan } \times \mathrm{h} \\
& =17 \times 2 \\
& =34 \mathrm{kN} / \mathrm{m}^{3} \\
& =0,34 \mathrm{~kg} / \mathrm{cm}^{2}
\end{aligned}
$$

2. Menghitung Area (A) menggunakan Persamaan 8.

$$
\begin{aligned}
\mathrm{A} & =0,25 \pi d^{\mathrm{Q}} \\
& =0,25 \pi 6^{2} \\
& =28,27 \mathrm{~cm}^{2}
\end{aligned}
$$

3. Menghitung Beban (P) menggunakan Persamaan 9.

$\mathrm{P}$

$=\sigma Y \times A$

$=0,34 \times 28,27$

$=9,613 \mathrm{~kg}$

$=9613 \mathrm{gr}$

$=9613 / 10$ (10 adalah koreksi lengan beban $)$

$=961,3 \mathrm{gr}$ 
Setelah mendapatkan besar beban (P), maka pengujian direct shear dapat dilakukan. Untuk nilai 1 beban, maka akan mendapatkan 1 kurva tegangan normal 1, untuk tegangan normal 2 dan 3, beban dikalikan 2 kali lipatnya.

\subsection{Penentuan $\gamma_{\mathrm{d}}$}

Berat isi tanah kering $\left(\gamma_{\mathrm{d}}\right)$ adalah perbandingan antara berat butiran $\left(\mathrm{W}_{\mathrm{s}}\right)$ dengan volume total $(\mathrm{V})$ tanah. Penentuan nilai $\gamma_{\mathrm{d}}$ adalah untuk mendapatkan berat sampel yang akan dipakai pada pengujian direct shear. Pada penelitian ini, nilai $\gamma_{\mathrm{d}}$ yang akan dihitung berdasarkan nilai angka pori yang telah ditetapkan. Pada pengujian sieve analysis berdasarkan Lampiran L.6 didapatkan jenis sampel uji well graded sand with gravel, dan berdasarkan Gambar 2.2 angka pori maksimum (keadaan pasir paling lepas) memiliki tipikal rentang 0,6-1,2. Maka dari itu, ditetapkan bahwa nilai angka pori untuk pengujian ini adalah 0,85 . Metode untuk menentukan besarnya nilai $\gamma_{\mathrm{d}}$ yang akan digunakan adalah:

a. Menentukan besarnya nilai specific gravity (Gs). Dari perhitungan didapatkan nilai Gs sebesar 2,80 .

b. Mengambil nilai $\gamma_{\mathrm{w}}$ sebesar $9,81 \mathrm{kN} / \mathrm{m}^{3}$.

c. Menetapkan nilai angka pori yaitu 0,85 .

d. Setelah mendapatkan nilai parameter yang dibutuhkan, maka $\gamma_{\mathrm{d}}$, dihitung menggunakan Persamaan 10.

$$
\gamma_{\mathrm{d}}=\frac{\operatorname{esxyw}}{\sin }
$$

Perhitungan manual untuk mendapatkan nilai $\gamma_{\mathrm{d}}$ dapat dilihat dibawah ini:

Diketahui:

$$
\begin{array}{ll}
\operatorname{Specific} \operatorname{Gravity}(\mathrm{Gs}) & =2,80 \\
\gamma_{\mathrm{w}} & =9,81 \mathrm{kN} / \mathrm{m}^{3} \\
\text { Angka pori (e) } & =0,85
\end{array}
$$

Cara pengerjaan untuk mendapatkan $\gamma_{\mathrm{d}}$ menggunakan Persamaan 10.

$$
\begin{aligned}
\gamma_{\mathrm{d}} & =\frac{\text { gxym }}{\cos 1} \\
& =\frac{28 \times 981}{1+0.8 \%} \\
& =14,841 \mathrm{kN} / \mathrm{m}^{3}
\end{aligned}
$$

Nilai $\gamma_{\mathrm{d}}$ yang telah didapatkan selanjutnya akan digunakan untuk menghitung berat sampel uji yang akan dimasukkan ke dalam pengujian direct shear. 


\section{ANALISIS DATA}

\subsection{Penamaan Sampel Uji}

Penamaan sampel yang akan diuji pada alat direct shear bertujuan untuk mempermudah pembacaan pada setiap sampel uji yaitu seperti contoh SU1NS1 yang berarti sampel uji 1 tanpa menggunakan geotekstil dengan normal stress 1 . Sedangkan SU2 yang berarti sampel uji 2 menggunakan geotekstil woven dan SU3 yang berarti sampel uji 3 menggunakan geotekstil non woven.

\subsection{Hasil Uji Indeks Properti Material Uji}

Hasil pengujian indeks properti yang sudah dilakukan pada beberapa sampel uji adalah kadar air, berat jenis, dan klasifikasi tanah. Pada Tabel 2 dapat dilihat hasil pengujian indeks properti.

Tabel 2. Hasil Pengujian Indeks Properti

\begin{tabular}{|c|c|c|c|c|}
\hline Sampel Uji & Normal Stress & $w \%$ (at test) & Gs & Group Name \\
\hline \multirow{3}{*}{ SU1 } & 1 & 12,47 & \multirow{9}{*}{2,80} & \multirow{9}{*}{ Well Graded Sand with Gravel } \\
\hline & 2 & 10,17 & & \\
\hline & 3 & 10,79 & & \\
\hline \multirow{3}{*}{ SU2 } & 1 & 7,83 & & \\
\hline & 2 & 10,97 & & \\
\hline & 3 & 9,41 & & \\
\hline \multirow{3}{*}{ SU3 } & 1 & 6,15 & & \\
\hline & 2 & 6,28 & & \\
\hline & 3 & 7,19 & & \\
\hline
\end{tabular}

\subsection{Gabungan Hasil Uji Direct Shear SU1}

Dari hasil uji direct shear US1 dengan 3 tegangan normal maka didapat kurva gabungan pada Gambar 7. Dengan menarik garis lurus pada kedua gambar tersebut maka dapat diperoleh nilai vertical deformation. Hasil uji gabungan direct shear pada US 1 untuk nilai normal stress, shear stress dan strain dapat dilihat pada Tabel 3 serta nilai vertical deformation saat tanah runtuh dapat dilihat pada Tabel 4. 


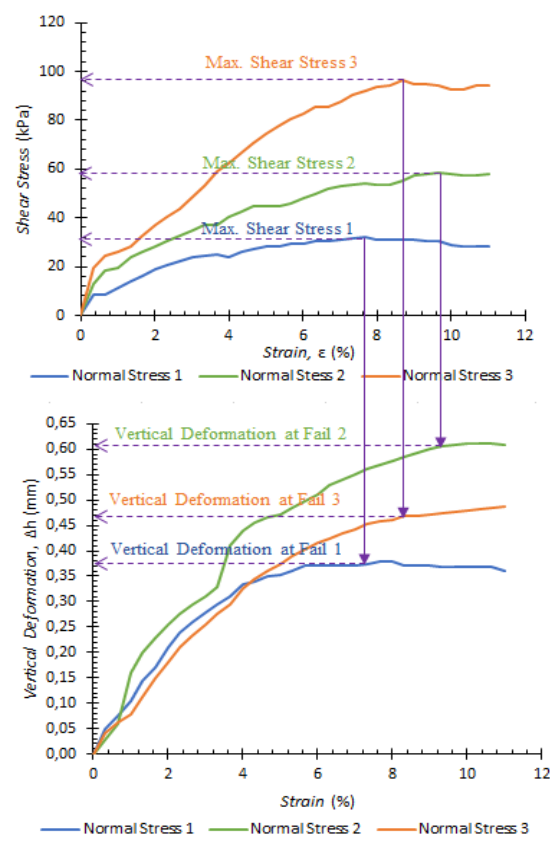

\section{Gambar 7 Kurva Hubungan Strain dan Shear Stress dengan Strain dan Vertical Deformation SU1}

Tabel 3 Hasil Uji Direct Shear SU1

\begin{tabular}{ccccc}
\hline No. & Sampel Uji & Normal Stress, $\boldsymbol{\sigma}_{\mathbf{n}}(\mathbf{k P a})$ & Shear Stress, $\boldsymbol{\tau}_{\mathbf{f}}(\mathbf{k P a})$ & $\begin{array}{c}\text { Strain, } \boldsymbol{\varepsilon}_{\mathbf{f}} \\
\mathbf{( \% )}\end{array}$ \\
\hline 1 & SU1NS1 & 34 & 32,01 & 7,667 \\
2 & SU1NS2 & 68 & 58,77 & 9,667 \\
3 & SU1NS3 & 136 & 96,26 & 8,667 \\
\hline
\end{tabular}

Tabel 4 Nilai Vertical Deformation pada SU1

\begin{tabular}{cc}
\hline Normal Stress & Vertical Deformation (mm) \\
\hline 1 & 0,378 \\
2 & 0,610 \\
3 & 0,470
\end{tabular}

\subsection{Hasil Nilai c dan $\phi$ untuk SU1}

Untuk menentukan nilai sudut geser dalam $(\phi)$ dan nilai kohesi (c) pada pengujian SU1 dilakukan dengan cara memplot nilai tegangan geser pada saat runtuh dengan nilai tegangan normal. Besar sudut geser dalam dapat dilihat pada Gambar 8. 
Berdasarkan Gambar 8 untuk SU1 dengan perlakuan kepada sampel uji tanpa menggunakan geotekstil didapat nilai sudut geser dalam $(\phi)$ sebesar $31,75^{\circ}$ dan nilai kohesi (c) sebesar $13 \mathrm{kPa}$.

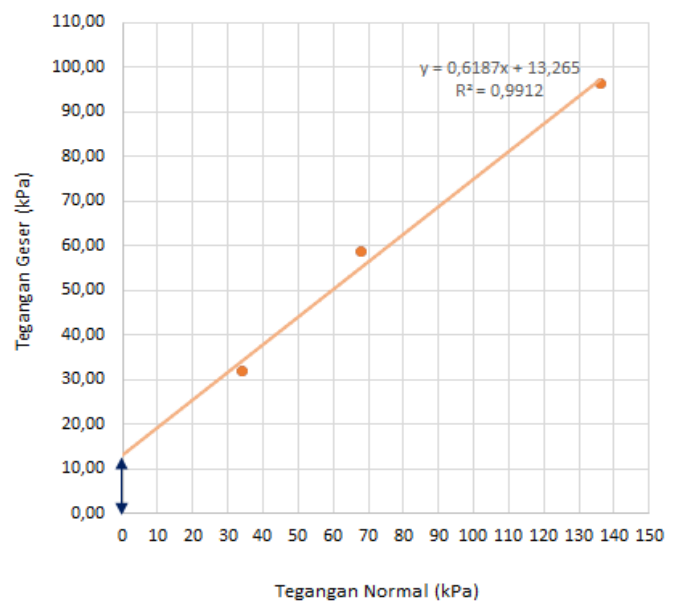

\section{Gambar 8. Kurva Hubungan Normal Stress vs Shear Stress pada SU1}

\subsection{Gabungan Hasil Uji Direct Shear SU2}

Dari hasil uji direct shear US 2 dengan 3 tegangan normal maka didapat kurva gabungan pada Gambar 9. Dengan menarik garis lurus pada kedua gambar tersebut maka dapat diperoleh nilai vertical deformation. Hasil uji gabungan direct shear pada US 2 untuk nilai normal stress, shear stress, dan strain dapat dilihat pada Tabel 5 serta nilai vertical deformation saat tanah runtuh dapat dilihat pada Tabel 6.

Tabel 5. Hasil Uji Direct Shear SU2

\begin{tabular}{ccccc}
\hline No. & Sampel Uji & $\begin{array}{c}\text { Normal Stress, } \boldsymbol{\sigma}_{\mathbf{n}} \\
(\mathbf{k P a})\end{array}$ & $\begin{array}{c}\text { Shear Stress, } \boldsymbol{\tau}_{\mathbf{f}} \\
(\mathbf{k P a})\end{array}$ & $\begin{array}{c}\text { Strain, } \boldsymbol{\varepsilon}_{\mathbf{f}} \\
\mathbf{( \% )}\end{array}$ \\
\hline 1 & SU2NS1 & 34 & 50,65 & 5,67 \\
2 & SU2NS2 & 68 & 94,29 & 11,0 \\
3 & SU2NS3 & 136 & 122,36 & 11,0 \\
\hline
\end{tabular}

Perbandingan Kuat Geser Tanah Pasir Menggunakan Geotextile Woven Dan Non Woven 
Tabel 6. Nilai Vertical Deformation pada SU2

\begin{tabular}{cc}
\hline Normal Stress & Vertical Deformation $(\mathbf{m m})$ \\
\hline 1 & 0,201 \\
2 & 0,369 \\
3 & 0,350 \\
\hline
\end{tabular}

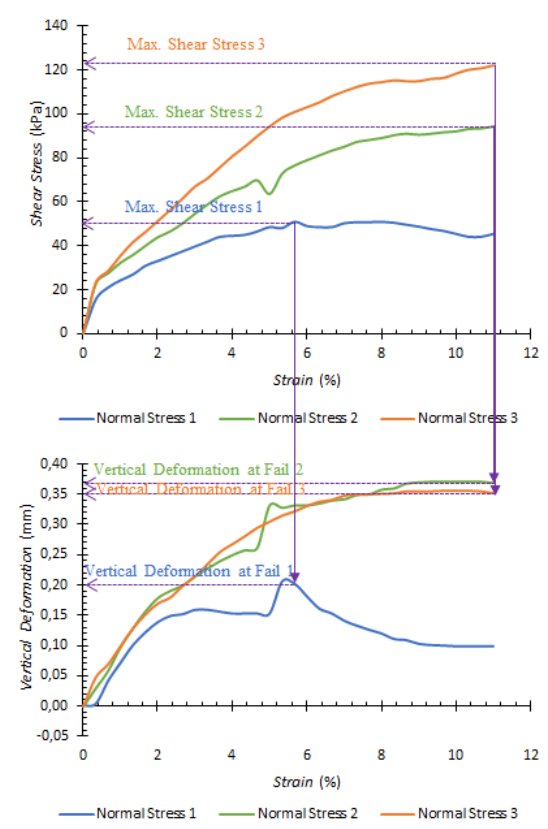

\section{Gambar 9. Kurva Hubungan Strain dan Shear Stress dengan Strain dan Vertical Deformation SU2}

Contoh perhitungan direct shear SU2NS1:

$$
\begin{array}{lll}
\text { Sample diameter }(\mathrm{D}) & =6 \mathrm{~cm} \\
\text { Sample area }(\mathrm{A}) & =28,27 \mathrm{~cm}^{2} \\
\text { Ring Constant } & =0,62 \mathrm{~kg} / \mathrm{div} \\
\text { Elapsed time } & =18.42 \\
\text { Horizontal dial } & =20 \mathrm{div} \\
\text { Vertical dial } & =0,3 \mathrm{div} \\
\text { Proving ring dial } & =7 \mathrm{div} \\
\text { Consolidated load } & =0,9613 \mathrm{~kg} \\
\text { Strain } & =(\text { horizontal dial } \times 0,01 / \text { diameter } \times 10) \times 100 \\
& =((20 \times 0,01) /(6 \times 10)) \times 100 \\
& =0,33 \%
\end{array}
$$




$$
\begin{aligned}
\text { Vertical displacement } & =\text { vertical dial } \times 0,01 \\
& =0,3 \times 0,01 \\
& =0,003 \mathrm{~mm} \\
& =\text { proving ring } x \text { ring constant } \\
& =7 \times 0,62 \\
& =4,34 \mathrm{~kg} \\
& =\text { shear force/area } \\
& =4,34 / 28,27 \\
\text { Shear Stress } & =0,153 \mathrm{~kg} / \mathrm{cm}^{2} \\
& =15,350 \mathrm{kPa} \\
& =(\text { consolidated load } \times 10) / \text { area } \\
& =(0,9613 \times 10) / 28,27 \\
\text { Normal stress } & =0,3785 \mathrm{~kg} / \mathrm{cm}^{2} \\
& =0,34 \mathrm{kPa}
\end{aligned}
$$

\subsection{Hasil Nilai c dan $\phi$ untuk SU2}

Untuk menentukan nilai sudut geser dalam $(\phi)$ dan nilai kohesi (c) pada pengujian SU1 dilakukan dengan cara memplot nilai tegangan geser pada saat runtuh dengan nilai tegangan normal. Besar sudut geser dalam dapat dilihat pada Gambar 10.

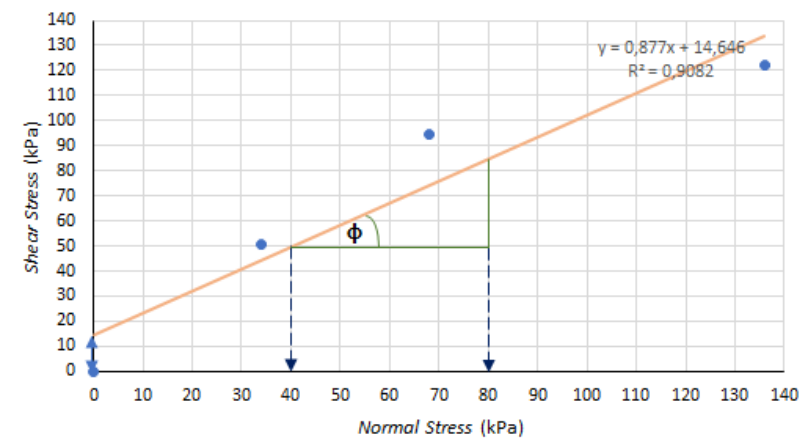

\section{Gambar 10. Kurva Hubungan Normal Stress vs Shear Stress pada SU2}

Berdasarkan Gambar 10 untuk SU2 dengan perlakuan kepada sampel uji tanpa menggunakan geotekstil didapat nilai sudut geser dalam $(\phi)$ sebesar $41,25^{\circ}$ dan nilai kohesi (c) sebesar 14,9kPa.

Perbandingan Kuat Geser Tanah Pasir Menggunakan Geotextile Woven Dan Non Woven 
Contoh perhitungan sudut geser dalam dan kohesi SU2:

$$
\begin{aligned}
\mathrm{X}_{1}=40 ; & \mathrm{X}_{2}=80 \\
\mathrm{Y}_{1} & =0,877\left(\mathrm{X}_{1}\right)+14,646 \\
& =0,877(40)+14,646 \\
& =49,73 \\
\mathrm{~A} \quad & \mathrm{Y}_{2}-\mathrm{Y}_{1} \\
& =84,81-49,73 \\
& =35,08 \\
\phi \quad & \arctan (\mathrm{A} / \mathrm{B}) \\
& =\arctan (35,08 / 40) \\
& =41,25
\end{aligned}
$$

$$
\begin{aligned}
\mathrm{Y}_{2} & =0,877\left(\mathrm{X}_{2}\right)+14,646 \\
& =0,877(80)+14,646 \\
& =84,81 \\
\mathrm{~B} & =\mathrm{X}_{2}-\mathrm{X}_{1} \\
& =80-40 \\
& =40
\end{aligned}
$$

Kohesi (c)

Diketahui:

$$
\begin{array}{ll}
\mathrm{x} & =0 \\
\mathrm{c} & =0,877(\mathrm{x})+14,646 \\
& =0,877(0)+14,646=14,646
\end{array}
$$

\subsection{Gabungan Hasil Uji Direct Shear SU3}

Dari hasil uji direct shear US 2 dengan 3 tegangan normal maka didapat kurva gabungan pada Gambar 11. Dengan menarik garis lurus pada kedua gambar tersebut maka dapat diperoleh nilai vertical deformation. Hasil uji gabungan direct shear pada US 3 untuk nilai normal stress, shear stress, dan strain dapat dilihat pada Tabel 7 serta nilai vertical deformation saat tanah runtuh dapat dilihat pada Tabel 8.

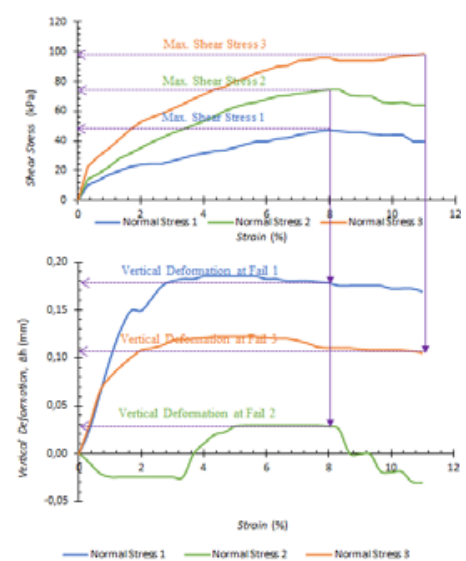

\section{Gambar 11. Kurva Hubungan Strain dan Shear Stress dengan Strain dan Vertical Deformation SU3}


Tabel 7. Hasil Uji Direct Shear SU3

\begin{tabular}{ccccc}
\hline No. & Sampel Uji & Normal Stress, $\boldsymbol{\sigma}_{\mathbf{n}}(\mathbf{k P a})$ & Shear Stress, $\boldsymbol{\tau}_{\mathbf{f}}(\mathbf{k P a})$ & $\begin{array}{c}\text { Strain, } \boldsymbol{\varepsilon}_{\mathbf{f}} \\
\mathbf{( \% )}\end{array}$ \\
\hline 1 & SU3NS1 & 34 & 47,36 & 8,0 \\
2 & SU3NS2 & 68 & 74,77 & 8,0 \\
3 & SU3NS3 & 136 & 98,24 & 11,0 \\
\hline
\end{tabular}

Tabel 8. Nilai Vertical Deformation pada SU3

\begin{tabular}{cc}
\hline Normal Stress & Vertical Deformation $(\mathbf{m m})$ \\
\hline 1 & 0,178 \\
2 & 0,03 \\
3 & 0,11 \\
\hline
\end{tabular}

\subsection{Hasil Nilai c dan $\phi$ untuk SU3}

Untuk menentukan nilai sudut geser dalam ( $\phi)$ dan nilai kohesi (c) pada pengujian SU1 dilakukan dengan cara memplot nilai tegangan geser pada saat runtuh dengan nilai tegangan normal. Besar sudut geser dalam dapat dilihat pada Gambar 12.

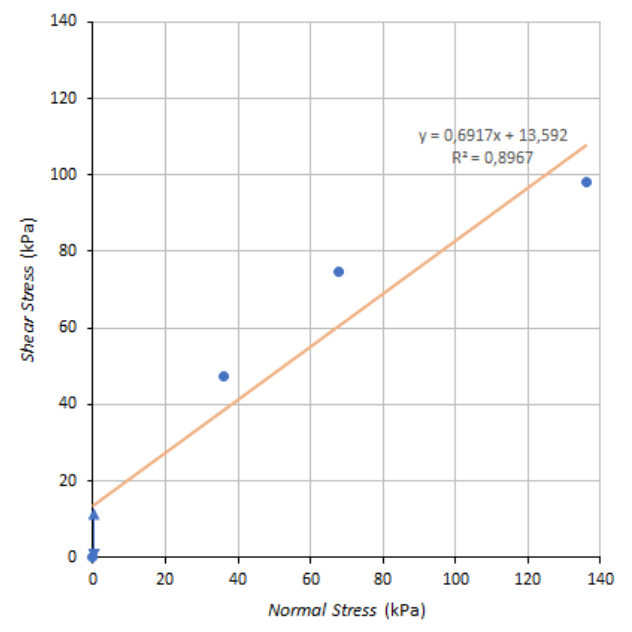

Gambar 12. Kurva Hubungan Normal Stress vs Shear Stress pada SU3

Berdasarkan Gambar 12 untuk SU3 dengan perlakuan kepada sampel uji tanpa menggunakan geotekstil didapat nilai sudut geser dalam $(\phi)$ sebesar $34,67^{\circ}$ dan nilai kohesi (c) sebesar $14 \mathrm{kPa}$. 


\subsection{Analisis Hubungan Antara Shear Stress dengan Strain pada Setiap Normal Stress dengan Penggunaan Geotekstil Woven, Non Woven dan Tanpa Geotekstil}

Hasil uji direct shear sampel uji dapat dilihat pada kurva tegangan-regangan pada Gambar 13, dan dapat dilihat pada Tabel 9.

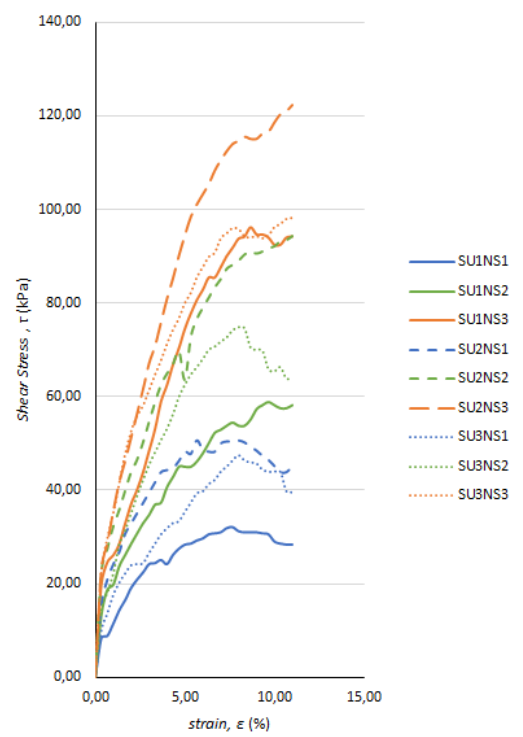

\section{Gambar 13. Kurva Tegangan-Regangan Gabungan}

Berdasarkan hasil pengujian pada Gambar 13 dan Tabel 9 didapatkan bahwa semakin tinggi tegangan normal yang digunakan maka semakin tinggi juga posisi shear stress $\left(\tau_{\mathrm{f}}\right)$ dan strain (\%) pada saat runtuh. Sementara akibat penggunaan geotekstil baik woven maupun non woven pada sampel uji, posisi shear stress $\left(\tau_{\mathrm{f}}\right)$ lebih besar dari pada sampel uji yang tanpa menggunakan geotekstil.

Tabel 9. Hasil Uji Tegangan-Regangan Gabungan

\begin{tabular}{clcc}
\hline No. & Sampel Uji & $\begin{array}{c}\text { Shear Stress, } \boldsymbol{\tau}_{\mathbf{f}} \\
(\mathbf{k P a})\end{array}$ & $\begin{array}{c}\text { Strain, } \boldsymbol{\varepsilon}_{\mathbf{f}} \\
\mathbf{( \% )}\end{array}$ \\
\hline 1 & SU1NS1 & 32,01 & 7,67 \\
2 & SU1NS2 & 58,77 & 9,67 \\
3 & SU1NS3 & 96,26 & 8,67 \\
4 & SU2NS1 & 50,65 & 5,67 \\
5 & SU2NS2 & 94,29 & 11,0 \\
6 & SU2NS3 & 122,36 & 11,0 \\
7 & SU3NS1 & 47,36 & 8,0 \\
\hline
\end{tabular}




\begin{tabular}{cccc}
\hline No. & Sampel Uji & $\begin{array}{c}\text { Shear Stress, } \boldsymbol{\tau}_{\mathbf{f}} \\
\mathbf{( k P a )}\end{array}$ & $\begin{array}{c}\text { Strain, } \boldsymbol{\varepsilon}_{\mathbf{f}} \\
\mathbf{( \% )}\end{array}$ \\
\hline 8 & SU3NS2 & 74,77 & 8,0 \\
9 & SU3NS3 & 98,24 & 11,0 \\
\hline
\end{tabular}

Hasil pengujian pada Gambar 14 dapat digunakan untuk melihat modulus elastisitas, E atau kekakuan dari tanah. Nilai E adalah rasio antara shear stress dan strain, $\frac{\Delta F}{\Delta e}$ seperti terlihat pada Gambar 14 Pada penelitian ini, nilai E hanya akan disimulasikan untuk normal stress 1 (NS1). Tabel 10 merupakan nilai E untuk setiap sampel uji normal stress 1. Nilai E atau identik dengan kekakuan pada SU2NS1 lebih besar dibandingkan dengan SU1NS1 dan SU3NS1. Hal ini dapat dikatakan bahwa SU2NS1 atau sampel uji yang menggunakan woven memiliki pengaruh yang signifikan untuk kuat geser tanah.

Tabel 10. Hasil Uji Hubungan $\frac{\Delta \tau}{\Delta c}$ pada Setiap Sampel Uji untuk Normal Stress 1

\begin{tabular}{cccc}
\hline Parameter & SU1 & SU2 & SU3 \\
\hline$E=\frac{\Delta T}{\Delta s}$ & $E=\frac{10}{4,75}=2,1$ & $E=\frac{10}{1.1}=9,09$ & $E=\frac{10}{2,3}=4,34$ \\
\hline
\end{tabular}

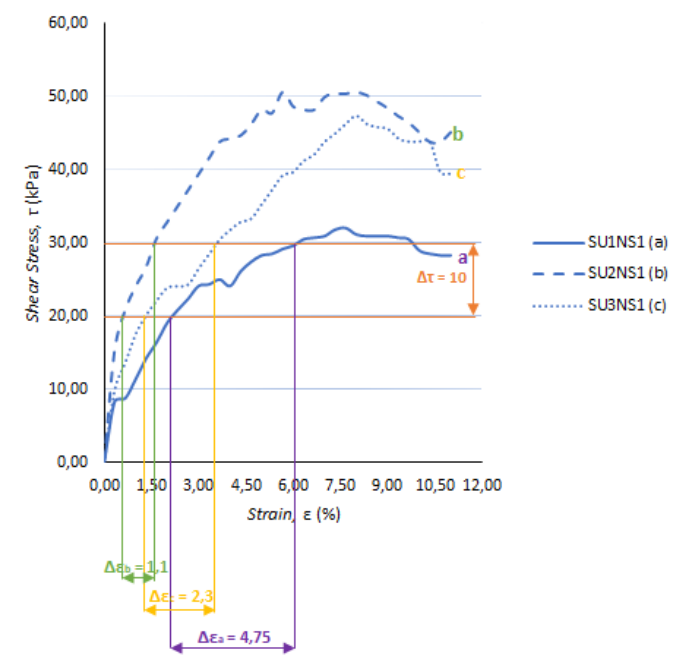

Gambar 14 Kurva Hubungan $\frac{\Delta_{T}}{\Delta \varepsilon}$ pada Setiap Sampel Uji untuk Normal Stress 1 


\subsection{Perbandingan Gabungan Parameter Kuat Geser c dan $\phi$ Terhadap Penggunaan Geotekstil}

Rangkuman data hasil pengujian dari direct shear dengan penggunaan geotekstil terhadap sampel uji, yaitu: tanpa menggunakan geotekstil, menggunakan geotekstil woven, dan non woven dapat dilihat pada Gambar 15 dan Tabel 11.

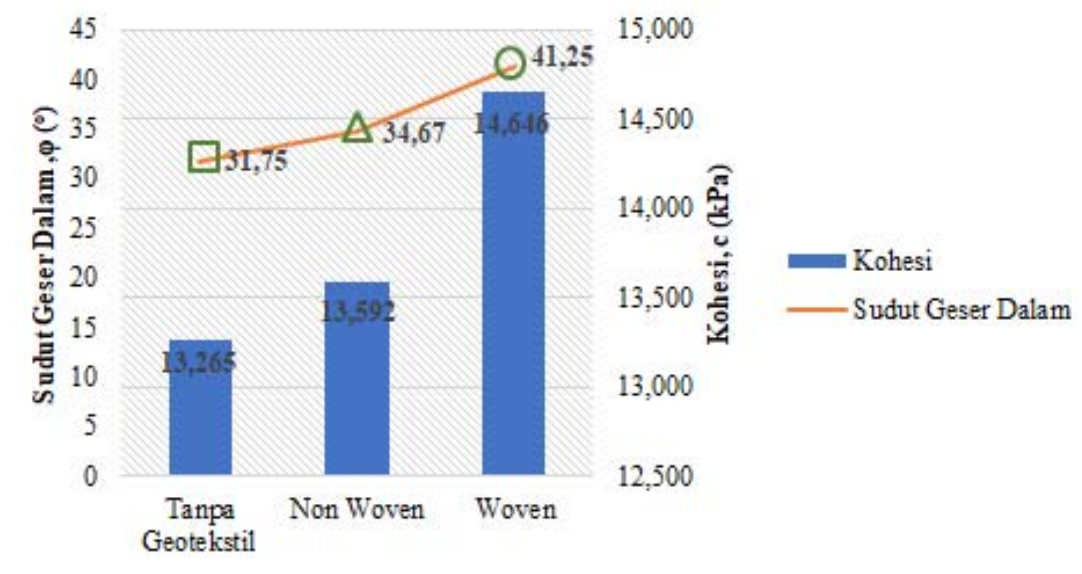

Gambar 15. Rangkuman Data Pengujian Direct Shear

Tabel 11. Rangkuman Data Pengujian Direct Shear

\begin{tabular}{cccc}
\hline Sampel Uji & Penggunaan & c (kPa) & $\boldsymbol{\phi}(\mathbf{d e g})$ \\
\hline SU1 & Tanpa Geotekstil & 13,265 & 31,75 \\
SU3 & Geotekstil Non Woven & 13,592 & 34,67 \\
SU2 & Geotekstil Woven & 14,646 & 41,25 \\
\hline
\end{tabular}

\section{KESIMPULAN}

Berdasarkan hasil pengujian direct shear tipe consolidated drained dan analisis data mengenai perbandingan kuat geser tanah pasir menggunakan geotextile woven dan non woven, maka diperoleh kesimpulan sebagai berikut:

1. Nilai kohesi (c) meningkat sejalan dengan penggunaan geotextile, baik jenis woven maupun non woven. Nilai kohesi (c) tanpa geotextile adalah 13,265kPa. Nilai kohesi pada sampel yang menggunakan geotextile non woven adalah sebesar $13,592 \mathrm{kPa}$. Nilai kohesi pada sampel yang menggunakan geotextile woven adalah $14,646 \mathrm{kPa}$.

2. Nilai sudut geser dalam $(\phi)$ meningkat sejalan dengan penggunaan geotextile, baik jenis woven maupun non woven. Nilai sudut geser dalam $(\phi)$ tanpa geotextile adalah 
$31,75^{\circ}$. Nilai sudut geser dalam $(\phi)$ pada sampel yang menggunakan geotextile non woven adalah sebesar $34,67^{\circ}$. Nilai sudut geser dalam $(\phi)$ pada sampel yang menggunakan geotextile woven adalah $41,25^{\circ}$.

Maka dapat dikatakan bahwa penggunaan geotextile woven lebih berpengaruh terhadap nilai sudut geser dalam $(\phi)$. Hal ini dikarenakan permukaan (interface) geotextile woven lebih kasar yang memiliki alur karena dirajut sedangkan geotextile non woven tidak memiliki alur dan lebih halus.

\section{DAFTAR PUSTAKA}

1. Adinanda, F., 2018, Pengaruh Kecepatan Geser Terhadap Parameter Kuat Geser Tanah Kohesif Berdasarkan Uji Direct Shear, Penelitian Program Studi S-1 Teknik Sipil UKM, tidak diterbitkan, Bandung.

2. Adoe, L., 2018, Pengaruh Konsistensi Terhadap Parameter Kuat Geser Tanah Kohesif Berdasarkan Uji Direct Shear Tipe Consolidated Drained, Penelitian Program Studi S-1 Teknik Sipil UKM, tidak diterbitkan, Bandung.

3. ASTM D3080 International, Standard Test Method for Direct Shear Test of Soils Under Consolidated Drained Condition, Pennsylvania.

4. Badan Standardisasi Nasional, 2008, Cara Uji Kuat Geser Langsung Tanah Terkonsolidasi dan Terdrainase, Indonesia

5. Briaud, J.L., 2013, Geotechnical Engineering: Unsaturated and Saturated SoilsI, Hoboken, New Jersey.

6. CivilTech., 2017, Allpile Version 7 User's Manual Volume 1 and 2, United States of America.

7. Das, B.M., 1994, Mekanika Tanah (Prinsip-prinsip Rekayasa Geoteknis) Jilid I, diterjemahkan oleh Endah, N., Mochtar, I.B., Erlangga, Jakarta.

8. Das, B.M., 1994, Mekanika Tanah (Prinsip-prinsip Rekayasa Geoteknis) Jilid II, diterjemahkan oleh Endah, N., Mochtar, I.B., Erlangga, Jakarta.

9. Hardiyatmo, H.C., 2002, Mekanika Tanah 1, Gajah Mada University Press, Yogyakarta.

10. Hardiyatmo, H.C., 2013, Geosintetik untuk Rekayasa Jalan Raya Perancangan dan Aplikasi, Gajah Mada University Press, Yogyakarta.

11. Holtz, R.D. and Kovacs, W.D., 1981, An Introduction to Geotechnical Engineering, Prentice Hall, New Jersey. 
12. Liberyanto, D., 2017, Pengaruh Siklus Kompaksi Terhadap Sudut Geser Dalam Material Crushed Limestone, Penelitian Program Studi S-1 Teknik Sipil UKM, tidak diterbitkan, Bandung.

13. Santosa, B., dkk, 1998, Dasar Mekanika Tanah, Gunadarma, Jakarta. 